PACS: 29.20.-c; 29.90.+r

\title{
DIGITAL TRIGGERING DEVICE AND GENERATOR OF STARTING PULSES FOR IGNITION OF SPARK GAPS OF REB ACCELERATOR "TEMP"
}

\author{
(D)Aleksey B. Batrakov*, (DEgeniy G. Glushko, (D)Andrey A. Zinchenko, (D)Yuriy F. Lonin, \\ (i) Anatoliy G. Ponomarev, (DSergei I. Fedotov \\ National Science Center "KhPTI" \\ Str. Akademichna 1, Kharkov, Ukraine, 61108 \\ *E-mail: a.batrakov67@gmail.com
}

Received September 26, 2019; revised November 15; accepted November 15, 2019

To ensure the controllability and high noise immunity while measuring the characteristics of the accelerators of relativistic electron beams (REB) "TEMP", and parameters of the processes in them, triggering devices with galvanic isolation of input and output circuits, allowing to set up the pulse delays in the range from $1 \mu$ s to tens of milliseconds, have been developed. When they are used, the effect of loop currents, which flow in the common ground circuits and affect the operation of the measuring equipment, is eliminated. To synchronize the operation of the REB accelerator "TEMP" a triggering device was developed and assembled. It was assembled from blocks produced on the up-to-date elemental base and is a complete functional product. The triggering device comprises a trigger block and delay units. The trigger block is developed on the basis of an AND - NOT chip and a multivibrator. The delay units are built on single-shot vibrators K155AG1 and differ in the value of adjustable delays, which are determined by the external elements R and C, connected to the multivibrator. Unfortunately, in case the millisecond delays are set up, the pulse drop on the multivibrator is not stable. Therefore, a digital triggering device was developed. The digital triggering device is built on the basis of digital microcircuits and consists of the following blocks: binary-decimal counters, decoders, and one oscillator with quartz frequency stabilization, which is common to all four channels. It contains four identical channels with delay adjustment from one microsecond to one hundred milliseconds. Such a pattern of the circuit allows, if necessary, adding channels for starting other units. Pulse signals of the triggering device are fed to the ignitor unit of the spark-gaps. A pulse generator for igniting the spark-gaps of the REB accelerator "TEMP" has been developed. A generator, designed to control the spark gaps ignition in the High Voltage Pulse Generator (HVPG) and spark gaps ignition in the magnetic systems, which are used in switching systems of the capacitor banks with the energy of $60 \div 150 \mathrm{~kJ}$, has been described. The generator provides voltage pulses with the amplitude of up to $20 \mathrm{kV}$, at the current in the short circuit mode of $5 \mathrm{~A}$, the pulse duration of the first half wave of $12 \mu \mathrm{s}$, and the pulse repetition frequency (PRF) of not more than $10 \mathrm{~Hz}$.

KEYWORDS: accelerator, relativistic electron beam, spark-gap, digital triggering device.

The REB accelerator "TEMP" is designed to produce high-power pulses of REB and X-ray bremsstrahlung (XRBS) with the energy of up to $150 \mathrm{~kJ}$. The devices allow obtaining a REB with the current of $2 \div 20 \mathrm{kA}$ and particle energy of $300 \div 800 \mathrm{keV}$. In this case the maximum dose of X-ray bremsstrahlung per current pulse can be obtained $\sim 9100$ R without induced activity. The REB accelerator "TEMP" comprises the following major components: a highvoltage pulse generator $(H V P G)$ with the circuits of charging, triggering and monitoring of the charging voltage; solenoids of magnetic systems intended to generate focusing and transporting REB of magnetic fields; a magnet; isolated vacuum diodes with diagnostic equipment, as well as vacuum pumping facilities, capable to maintain the working pressure in the diodes at the level of $1 \cdot 10^{-4} \mathrm{~Pa}$. For the successful functioning of the Radiation Beam Complex (RBC) of "TEMP" a reliable operation of its numerous units is required. This is achieved by the stable triggering of its systems [1]. In the process of the REB "TEMP" accelerator operation some transient current and voltage steps occur, causing electromagnetic fields, which can produce loop currents flowing in common ground buses and in connecting cables. The currents flowing in the wires, connecting various units of the REB accelerator "TEMP", can reach considerable values, what causes uncontrolled starts of its devices or failure in its operation. A radical method of controlling the disturbances of this type is galvanic isolation of all the circuits, connecting the synchronization system with the pulse sources and registering apparatus.

Object of the work: for better controllability of the REB accelerator "TEMP" to develop a triggering device that would allow setting up the pulse delays in the range from $1 \mu$ s to tens of milliseconds. The digital triggering device should stably and accurately preset the start-up time of the REB accelerator "TEMP" units under the strong electromagnetic interference caused by its operation, and have a galvanic isolation for improving the noise immunity and low power consumption.

To develop a pulse generator for igniting spark-gaps of High-Voltage Pulse Generator (HVPG), which allows obtaining an ignitor pulse several times higher than that of similar devices. To develop a scheme of the ignitor pulse generator, which would reliably and stably control the accelerator spark gaps operation.

\section{TRIGGERING DEVICES}

To synchronize the operation of the REB accelerator "TEMP" a triggering device was developed and assembled. A simple circuit, providing a galvanic isolation of the input and output circuits of the synchronization system, is proposed, what allows eliminating the occurrence of pulsed currents caused by operation of various accelerator units. 
The triggering device was assembled from blocks, produced on the up-to-date elemental base, and is a complete functional product. The triggering device comprises a trigger block and delay units. The schemes of the input part and the delay channel of the triggering device are presented in Fig. 1 and Fig. 2, respectively.

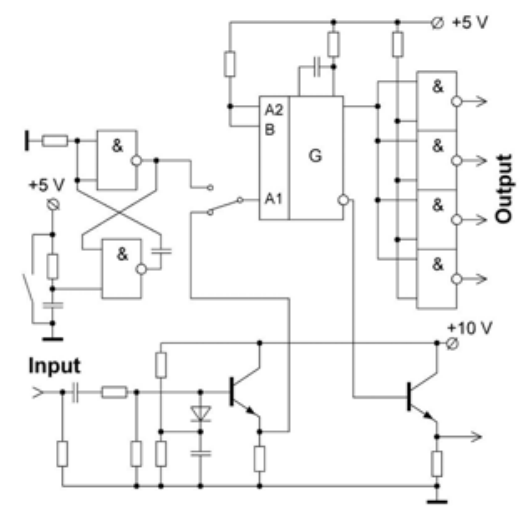

Fig. 1. Schematic diagram of the input part of the triggering device

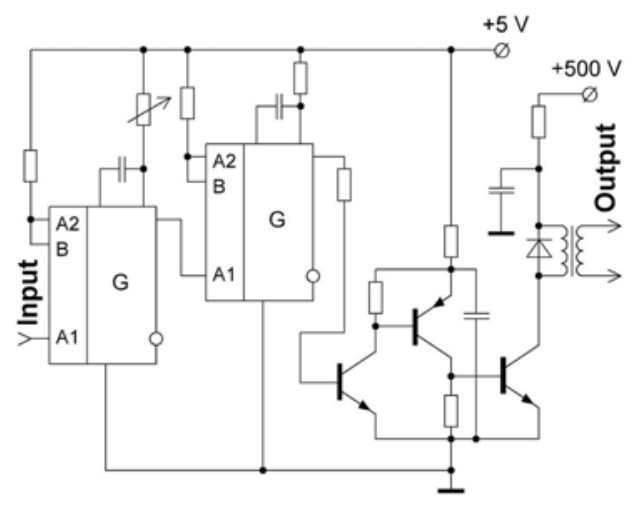

Fig. 2. Schematic diagram of the delay channel of the triggering device.

The trigger block is built on the basis of an AND NOT chip and a multivibrator. It allows triggering both manually and by an external positive pulse with the amplitude of up to $50 \mathrm{~V}$. The delay units are built on single-shot multivibrators K155AG1 and differ in the number of adjustable delays, which are determined by the external elements $\mathrm{R}$ and $\mathrm{C}$, connected to the multivibrator. The output pulse shaper is based on a multivibrator and three transistors. The output positive pulse amplitude makes $500 \mathrm{~V}$. Channel \# 1 provides triggering of the cone-shaped solenoid of the first magnetic field without delay. Channel \# 2 provides triggering of a cylindrical solenoid of the second magnetic field with the delay of $20 \mathrm{~ms}$, which is adjustable with the time step-interval of $0.2 \mathrm{~ms} \div 20 \mathrm{~ms}$. Channel \# 3 is triggered from channel \# 2 and provides the oscilloscope start with the delay of $5 \mathrm{~ms}$ and adjustment of $0.1 \mathrm{~ms} \div 10 \mathrm{~ms}$. Channel \# 4 is triggered from channel \# 3 and provides the start of the high-voltage pulse generator (HVPG) with the delay of $100 \mu$ s and adjustment of $10 \mu \mathrm{s} \div 100 \mu \mathrm{s}$. The delay setting accuracy is not worse than one percent at each range; time resolution is 0.001 of the range duration. All the channels of the delayed pulses of synchronization system have one common power source; the output cascades are galvanically isolated by optical couplers with the common synchronization system. The oscillogram of the control pulses and the total magnetic field distribution along the axis of the accelerating column, when two solenoids are triggered, is shown in Fig. 3.

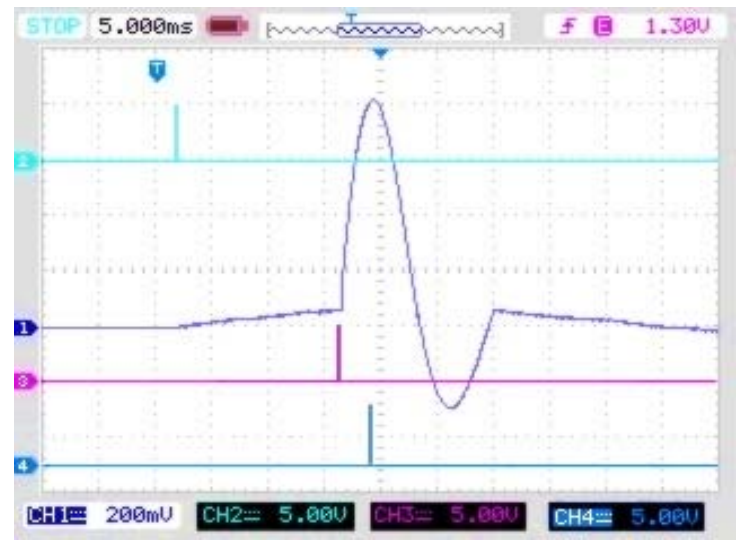

Fig. 3. Oscillogram of the control pulses and of the total magnetic field strength distribution along the axis of the accelerator column

In Fig. 3 beam 1 is the total magnetic field distribution along the axis of the accelerating column, beam 2 is the trigger pulse of the first solenoid, beam 3 is the trigger pulse of the second solenoid, beam 4 is the HVPG trigger pulse. Unfortunately, when the millisecond delays are set up, the pulse drop on the multivibrator is not stable. The errors at triggering of the first channel cause the failure of the entire device. Therefore, a new digital device of trigger pulses was developed and manufactured. To improve the noise immunity, the digital triggering device has a galvanic isolation of all the circuits, connecting the device to various units of the facilities. The galvanic isolation eliminates the flow of the pulsed currents caused by the operation of various units of the accelerators. The triggering device is based on digital chips [2] and consists of the following units: binary-decimal counters, decoders, and one generator with quartz frequency stabilization, which is common to all four channels. The triggering device contains four identical channels with adjustable delay, ranging from one microsecond to one hundred milliseconds. Such a construction of the scheme allows, if necessary, adding channels to trigger some other units. The delay adjustment is performed using decoders. 
The triggering device works as follows: the input trigger $(\mathrm{T})$ is started both manually and by an external positive pulse with the amplitude of up to $50 \mathrm{~V}$, and allows pulses propagation from the crystal oscillator (G) to 5 binary-decimal counters (CT1-CT5) with decoders (DC1-DC5). The crystal oscillator frequency is $1 \mathrm{MHz}$. Each channel has its own decoder $\left(\mathrm{DC}_{\mathrm{k} 1}-\mathrm{DC}_{\mathrm{k} 4}\right)$, which allows setting up the necessary delay of the trigger pulse. The delay is adjustable from $1 \mu \mathrm{s}$ to $100 \mathrm{~ms}$. After the counters are filled up the last pulse resets the input trigger and sets the counters to zero initial state. The device is ready for the next external start. The block diagram of the triggering device is presented in Fig. 4.

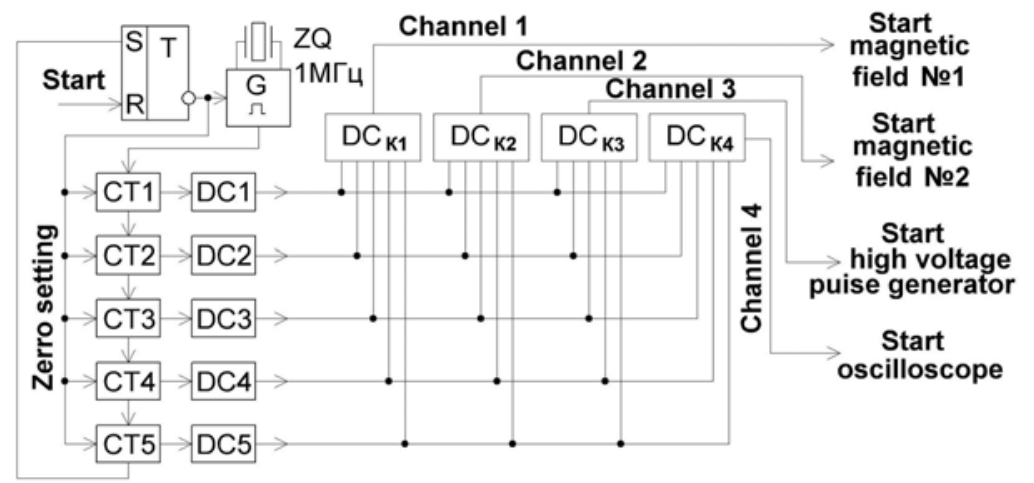

Fig. 4. Block diagram of the digital triggering device

The digital triggering device generates pulses for starting the dischargers of the conical and cylindrical solenoids [3]. They allow creating conditions for magnetic isolation and beam transport. The delay in start of the discharger of the cylindrical solenoid is about $15 \mathrm{~ms}$. The magnetic field strength of the conical solenoid makes $4 \mathrm{kOe}$, and that of the cylindrical solenoid is $11.7 \mathrm{kOe}$. In case a digital triggering device is used, the high-voltage pulse generator is started at the moment of the highest intensity of the magnetic fields in the solenoids. A typical oscillogram of the REB current and voltage in the REB accelerator "TEMP", obtained using the developed digital triggering device, is shown in Fig. 5.

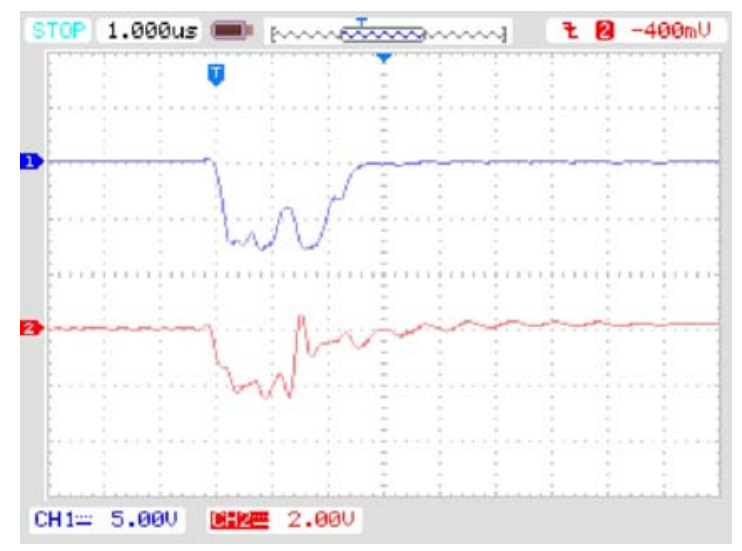

Fig. 5. Oscillogram of the REB current and voltage in the accelerator "TEMP-B"

In Fig. 5 the upper beam corresponds to the HVPG voltage of $750 \mathrm{kV}$, and the lower beam corresponds to the REB current of about $20 \mathrm{kA}$. The duration of the REB current pulse is about $1.5 \mu \mathrm{s}$. The developed digital triggering device allows the accelerator to work stably in the normal mode.

\section{GENERATOR OF STARTING PULSES FOR IGNITION OF SPARK GAPS}

For galvanic isolation of the triggering device from the REB accelerator "TEMP" some pulse transformers and starting pulse receivers with low input resistance are used, what significantly reduces the interference influence in the connecting cables. Pulse signals of the triggering device are supplied to the spark gap ignition unit. A circuit based on a transistor high-voltage pulse shaper was developed. The generator provides voltage pulses with the amplitude of up to $20 \mathrm{kV}$, current in the short circuit mode of $5 \mathrm{~A}$, pulse duration of the first half wave of $12 \mu \mathrm{s}$, and pulse repetition frequency of not more than $10 \mathrm{~Hz}$.

Schematic diagram of the generator for spark gaps ignition in HVPG and for the ignition of the spark gaps in the magnetic systems is presented in Fig. 6.

The circuit comprises: an isolation transformer T1, a voltage doubler made on VD1, VD2, C1, C2, storage capacitors $\mathrm{C} 3, \mathrm{C} 4$, a switch based on a triac VD6, a step-up pulse transformer T3, from the secondary winding of which the signal is fed to the control electrode of the spark gap. As the switch, a BTA41-800B triac is used, which provides a discharge of the storage capacitors to the high-voltage transformer. The transformation coefficient of T3 transformer 
is 35. The secondary high-voltage winding of the transformer consists of 4 sections and allows obtaining the ignitor pulse of about $20 \mathrm{kV}$. The developed pulse generator for ignition of spark gaps allows obtaining an ignition pulse several times higher than that in similar devices [4]. The oscillogram of the voltage pulse is shown in Fig. 7. Fig. 8 presents the current oscillogram, obtained in the short circuit mode.

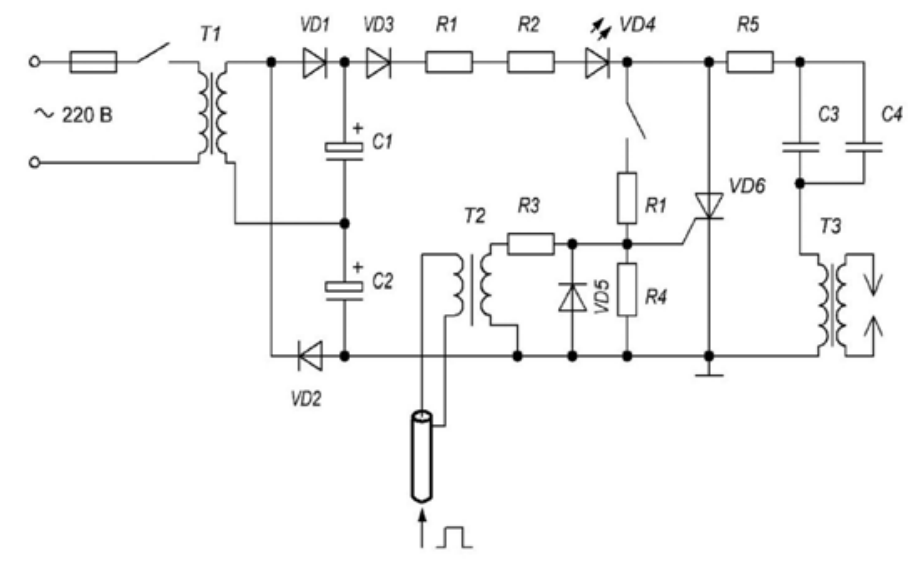

Fig. 6. Schematic diagram of spark gaps ignition circuit

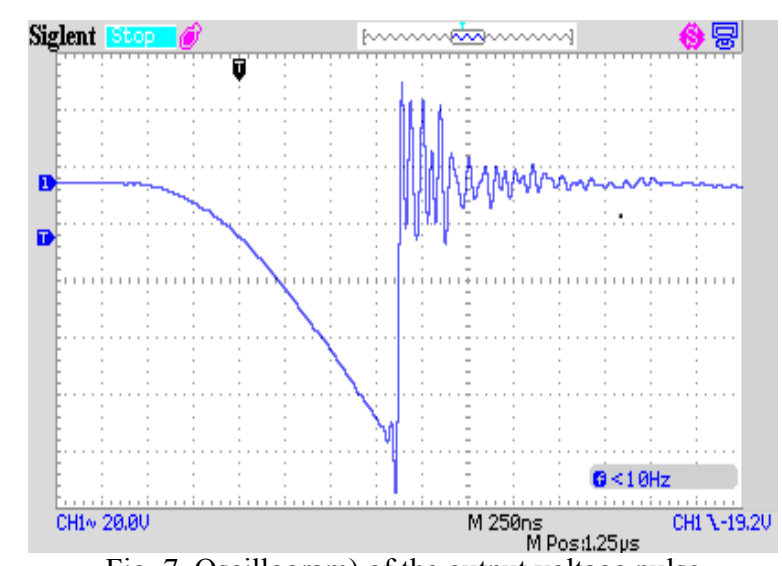

Fig. 7. Oscillogram) of the output voltage pulse in the idling mode

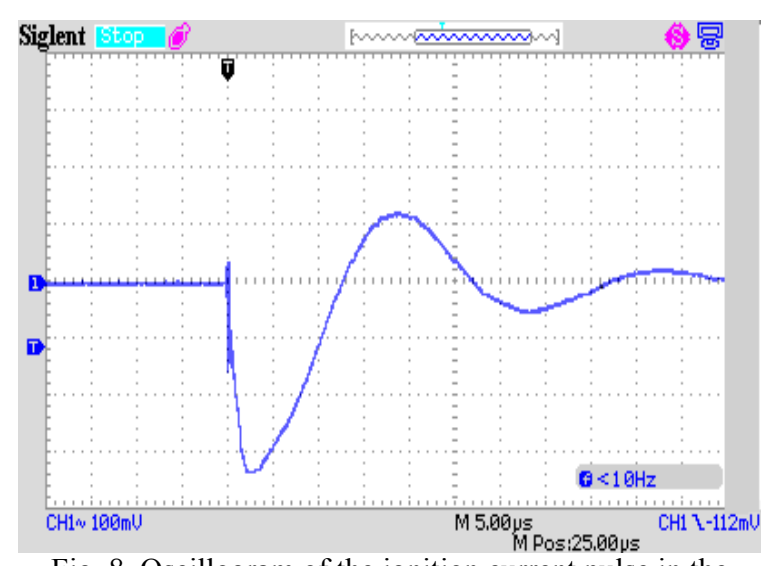

Fig. 8. Oscillogram of the ignition current pulse in the short circuit mode on the resistive load of $0.13 \mathrm{Ohms}$

The maximum value of the current that flows in the discharge circuit is determined by the inductance of the transformer primary winding and makes about $40 \mathrm{~A}$.

The triac VD6 control pulse comes from the triggering device via the pulse isolating transformer T2 and the current-limiting resistor R3. The control pulse for starting the VD6 triac has a positive polarity with the amplitude of $15 \mathrm{~V}$ and the duration of $4 \mu \mathrm{s}$. Resistors R1, R2 are used to limit the charge current of storage capacitors C3, C4. Resistor R5 limits the discharge current of capacitors C3, C4 to $400 \mathrm{~A}$. The indication of the ignition generator operation is performed using the light-emitting diode VD4.

The presented scheme of the ignition pulse generator allowed obtaining a stable triggering of the high-voltage spark gaps and can be utilized in the power systems of HVPGs and HCPGs (high-current pulse generators), used to solve various technological tasks, which are applied for changing the properties of the condensed matters and modification of the surfaces of polycomposite materials, [5].

\section{CONCLUSION}

The digital triggering device allows to preset stably and accurately the start-up time of the REB accelerator "TEMP" units under the strong electromagnetic interference, resulting from its operation, it has a galvanic isolation for improving the noise immunity and low power consumption.

The developed pulse generator for ignition of spark gaps allows obtaining an ignitor pulse several times higher than that in similar devices. The developed circuit of the ignition pulse generator allows controlling reliably and stably the operation of the accelerator spark gaps.

\section{ORCID IDs}

(iD)Aleksey B. Batrakov https://orcid.org/0000-0001-6158-2129, (Dugeniy G. Glushko https://orcid.org/0000-0001-8398-9915, (D)Andrey A. Zinchenko https://orcid.org/0000-0002-0534-1918, (D) Yriy F. Lonin https://orcid.org/0000-0003-2601-5035,

(iD)Anatoliy G. Ponomarev https://orcid.org/0000-0001-6914-6057, (DSergei I. Fedotov https://orcid.org/0000-0002-7216-0615 


\section{REFERENCES}

[1] V.V. Zhiznevsky, A.A. Turchin and A.A. Turchin, Problems of Atomic Science and Technology, 4, 376-380 (2010), in: https://vant.kipt.kharkov.ua. (in Russian)

[2] V.L. Shilo, Популярные цифровые микросхемы [Рориlar digital microchip], (Радио и связь, Moscow, 1987). (in Russian)

[3] A.B. Batrakov, E.G. Glushko, A.A. Zinchenko, Yu.F. Lonin, A.G. Ponomaryov, S.I. Fedotov, Problems of Atomic Science and Technology. Series: Plasma electronics and new methods of acceleration, 4, 7-9 (2013), in: https://vant.kipt.kharkov.ua. (in Russian)

[4] E.G. Krastelyov, Instruments and experimental equipment, 6, 51-56 (2014);

[5] D.V. Vinnikov, K.V. Korytchenko, V.I. Tkachev, V.V. Egorenkov, D.V. Kudin and T.Yu. Mirnaya, Electrical Engineering \& Electromechanics, 1, 39-46 (2017), https://doi.org/10.20998/2074-272X.2017.1.07.

\section{ЦИФРОВИЙ ПРИСТРІЙ ЗАПУСКАЮЧИХ ІМПУЛЬСІВ ТА ГЕНЕРАТОР ЗАПУСКАЮЧИХ ІМПУЛЬСІВ ДЛЯ ПІДПАЛУ РОЗРЯДНИКІВ ПРИСКОРЮВАЧА РЕП «ТЕМП»}

\section{О.Б. Батраков, Е.Г. Глушко, А.О. Зінченко, Ю.Ф. Лонін, А.Г. Пономарев, С.І. Федотов} Наиіональний науковий иентр «Харківський фізико-технічний інститут» вул. Академічна 1, Харків, Украӥна, 61108

Для забезпечення керованості та високої завадостійкості вимірювань характеристик і параметрів процесів для прискорювачів релятівістскіх електронних пучків (РЕП) «ТЕМП» були розроблені запускаючі пристрої 3 гальванічною розв'язкою вхідних і вихідних ланцюгів, які дозволяють встановлювати затримки імпульсів в діапазоні від 1 мкс до десятків мілісекунд. При їх використанні усувається вплив контурних струмів, які протікають в загальних колах заземлення $\mathrm{i}$ впливають на роботу вимірювальної апаратури. Для синхронізування роботи прискорювача РЕП «ТЕМП» було розроблено та зібрано запускаючий пристрій. Його було зібрано з блоків на сучасній елементній базі і він $є$ закінченим функціональним виробом. Запускаючий пристрій складається з блоку запуску і блоків затримок. Блок запуску побудований на основі мікросхеми I HE і мультивібратора. Блоки затримок побудовані на одневібраторах К155АГ1 і відрізняються рівнем регульованих затримок, які визначаються зовнішніми елементами R i C, підключеними до мультивібратора. На жаль при установці мілісекундних затримок спад імпульсу на мультивібраторі не стабільний. Тому було розроблено цифровий запускаючий пристрій. Цифровий запускаючий пристрій виконано на цифрових мікросхемах і складається 3 блоків: двійковіх-десяткових лічильників, дешифраторів і одного загального на всі чотири канали генератора 3 кварцовою стабілізацією частоти. Воно містить чотири ідентичних канали з регулюванням затримки від однієї мікросекунди до ста мілісекунд. Така побудова схеми дозволяє в разі необхідності додати канали для запуску інших вузлів. Імпульсні сигнали запускаючего пристрою подаються на блок підпалу розрядників. Розроблено генератор імпульсів запалювання розрядників прискорювача РЕП «ТЕМП». Наведено опис генератора, розробленого для управління розрядниками підпалу ГІНа $\mathrm{i}$ розрядниками підпалу магнітних систем, що використовуються в системах комутації конденсаторних батарей 3 енергозапаси від 60 до 150 кДж. Генератор забезпечує отримання імпульсів напруги 3 амплітудою до 20 кВ, при струмі в режимі короткого замикання 5 А, тривалості імпульсу першої напівхвилі 12 мкс, частоті повторення імпульсів не більше 10 Гц.

КЛЮЧОВІ СЛОВА: прискорювач, релятивістський електронний пучок, розрядник, цифровий запускаючий пристрій.

\section{ЦИФРОВОЕ ЗАПУСКАЮЩЕЕ УСТРОЙСТВО И ГЕНЕРАТОР ЗАПУСКАЮЩИХ ИМПУЛЬСОВ ДЛЯ ПОДЖИГА РАЗРЯДНИКОВ УСКОРИТЕЛЯ РЭП «ТЕМП» А.Б. Батраков, Е.Г. Глушко, А.А. Зинченко, Ю.Ф. Лонин, А.Г. Пономарев, С.И. Федотов Национальный научный центр «Харьковский физико-технический институт» ул. Академическая 1, Харьков, Украина, 61108}

Для обеспечения управляемости и высокой помехоустойчивости измерений характеристик и параметров процессов для ускорителей релятивистских электронных пучков (РЭП) «ТЕМП» были разработаны запускающие устройства с гальванической развязкой входных и выходных цепей, которые позволяют устанавливать задержки импульсов в диапазоне от 1 мкс до десятков миллисекунд. При их использовании устраняется влияние контурных токов, которые протекают в общих цепях заземления и влияют на работу измерительной аппаратуры. Для синхронизации работы ускорителя РЭП «ТЕМП» было разработано и собрано запускающее устройство. Оно было собрано из блоков на современной элементной базе и представляет собой законченное функциональное изделие. Запускающее устройство состоит из блока запуска и блоков задержек. Блок запуска построен на основе микросхемы И НЕ и мультивибратора. Блоки задержек построены на одновибраторах К155АГ1 и отличаются величиной регулируемых задержек, которые определяются внешними элементами $\mathrm{R}$ и $\mathrm{C}$, подключёнными к мультивибратору. К сожалению, при установке миллисекундных задержек спад импульса на мультивибраторе не стабилен. Поэтому было разработано цифровое запускающее устройство. Цифровое запускающее устройство выполнено на цифровых микросхемах и состоит из блоков: двоично-десятичных счетчиков, дешифраторов и одного общего на все четыре канала генератора с кварцевой стабилизацией частоты. Оно содержит четыре идентичных канала с регулировкой задержки от одной микросекунды до ста миллисекунд. Такое построение схемы позволяет в случае необходимости добавить каналы для запуска других узлов. Импульсные сигналы запускающего устройства подаются на блок поджига разрядников. Разработан генератор импульсов поджига разрядников ускорителя РЭП «ТЕМП». Приведено описание генератора, разработанного для управления разрядниками поджига Генератора импульсного напряжения (ГИНа) и разрядниками поджига магнитных систем, используемыми в системах коммутации конденсаторных батарей с энергозапасом от 60 до 150 кДж. Генератор обеспечивает получение импульсов напряжения с амплитудой до 20 кВ, при токе в режиме короткого замыкания 5 А, длительности импульса первой полуволны 12 мкс, частоте повторения импульсов не более 10 Гц.

КЛЮЧЕВЫЕ СЛОВА: ускоритель, релятивистский электронный пучок, разрядник, цифровое запускающее устройство 